CZASOPISMO INŻYNIERII LĄDOWEJ, ŚRODOWISKA I ARCHITEKTURY JOURNAL OF CIVIL ENGINEERING, ENVIRONMENT AND ARCHITECTURE

JCEEA, t. XXXIII, z. 63 (1/I/16), styczeń-marzec 2016, s. 97-106

\author{
Mariusz DĄBROWSKI ${ }^{1}$ \\ Karolina GIBAS ${ }^{2}$ \\ Andrzej M. BRANDT ${ }^{3}$ \\ Michał A. GLINICKI ${ }^{4}$
}

\title{
WPLYW KRUSZYW SPECJALNYCH NA POROWATOŚĆ I PRZEPUSZCZALNOŚĆ BETONÓW OSŁONOWYCH
}

\begin{abstract}
Przedstawiono wyniki badań podciągania kapilarnego $(P K)$, porowatości dostępnej dla wody $(E)$ oraz współczynnika migracji jonów chlorkowych w stanie nieustalonym $\left(D_{n s s m}\right)$. Zakres badań obejmował betony z kruszywem magnetytowym, barytowym, serpentynitowym oraz kruszywem referencyjnym w postaci grysu amfibolitowego, które wcześniej poddane zostały selektywnemu kruszeniu i przesiewaniu, tak by zapewnić jednakowe krzywe uziarnienia/stosy okruchowe. Przeanalizowano wpływ mikrostruktury porów wyznaczonej za pomocą porozymetrii rtęciowej z odpornością na wnikanie jonów i cieczy w matrycę cementową. Z badań wynika, że betony z kruszywami specjalnymi osiągają wskaźniki przepuszczalności porównywalne lub nieco gorsze niż próbki referencyjne. Nie zaobserwowano systematycznego wpływu porowatości kapilarnej na wyniki badań przepuszczalności.
\end{abstract}

Słowa kluczowe: podciąganie kapilarne, migracja jonów chlorkowych, kruszywo magnetytowe, kruszywo barytowe, kruszywo serpentynitowe, porowatość

\section{Wprowadzenie}

Stosowanie kruszyw specjalnych w betonach osłonowych ma szczególne znaczenie $\mathrm{z}$ uwagi na występujące $\mathrm{w}$ nich pierwiastki chemiczne osłabiające działanie promieniowania jonizującego. Kruszywa ciężkie w postaci rud magnetytu, barytu, hematytu, zawierające związki chemiczne z pierwiastkami o dużej masie atomowej, wykazują zdolność osłabiania promieniowania $\gamma$.

\footnotetext{
${ }^{1}$ Autor do korespondencji/corresponding author: Mariusz Dąbrowski, IPPT PAN, Pawińskiego 5B, 02-106 Warszawa, tel. 22 8261281, mdabrow@ippt.pan.pl

${ }^{2}$ Karolina Gibas, IPPT PAN, kgibas@ippt.pan.pl

${ }^{3}$ Andrzej M. Brandt, IPPT PAN, abrandt@ippt.pan.pl

${ }^{4}$ Michał A. Glinicki, IPPT PAN, mglinic@ippt.pan.pl
} 
Kruszywa ze związkami o małej liczbie atomowej, zawierające wodę związaną chemicznie oraz związki boru, wykazują zdolność osłabiania promieniowania neutronowego [1]. Główną korzyść wynikającą z użycia kruszyw specjalnych stanowi zmniejszenie grubości osłony biologicznej przy zachowaniu właściwości osłonowych w porównaniu z betonami z kruszywem zwykłym [2].

$\mathrm{W}$ przypadku konstrukcji osłonowych stykających się $\mathrm{z}$ gruntem istnieje możliwość transportu wilgoci do wnętrza materiału. Wraz z wilgocią do betonu mogą wnikać także zanieczyszczenia pojawiające się w wodach gruntowych (jony siarczanowe, chlorkowe). Dodatkowo warunki pracy reaktora, tj. zmienność temperatury w czasie w cyklu pracy reaktora, wymusza transport wilgoci w betonie osłonowym. Z monografii Bazanta i Kaplana [3] wynika, że transport wilgoci sprzężony $\mathrm{z}$ oddziaływaniami termicznymi $\mathrm{w}$ betonach osłonowych wpływa na długotrwałą stabilność właściwości mechanicznych. Kolejnym aspektem istotności ograniczenia przepuszczalności betonów osłonowych jest zabezpieczenie otoczenia przed wydostaniem się z reaktora potencjalnie skażonych cieczy i gazów.

Kruszywa specjalne na ogół są skałami o małej twardości, co utrudnia ich skruszenie do pożądanego uziarnienia. Niekorzystny rozkład ziaren wynikający z dużej zawartości pyłów utrudnia wykorzystanie kruszyw specjalnych w betonach o niskich wskaźnikach $w / c$. Powyższe niedogodności wpływają na właściwości betonów osłonowych. Stąd celem badań jest ocena szczelności betonów na podstawie testów przepuszczalności i porowatości betonu.

\section{Opis metod doświadczalnych}

\subsection{Materiały i próbki}

Program badań obejmował analizę porównawczą mikrostruktury i przepuszczalności czterech betonów zaprojektowanych zgodnie z założeniami zamieszczonymi w publikacji [4]. Przy założonej klasie betonu: C30/37, określono proporcje składników w betonie referencyjnym z kruszywem zwykłym. Zawartość cementu wynosiła $350 \mathrm{~kg} / \mathrm{m}^{3}$ przy współczynniku wodno-cementowym 0,48 . Kryterium wyboru kruszywa zwykłego była jego dobra jakość. Grys amfibolitowy pochodzący ze skały zwięzłej zapewnił zakładane parametry, typowe w przypadku kruszyw w odpowiedzialnych konstrukcjach inżynierskich [4]. Następnie ustalono zawartość piasku kwarcowego frakcji 0-2 mm, która stanowiła $20 \%$ objętości stosu okruchowego i była stała we wszystkich seriach betonów.

Dobór parametrów technologicznych był ukierunkowany na możliwość wykonania, transportu i wbudowania projektowanego betonu dostępnymi obecnie środkami technicznymi. Stąd założono konsystencję 50-100 mm opadu stożka, która była kompromisem między właściwą urabialnością, a tendencją do segregowania się składników mieszanki. 
Zastosowano cement hutniczy o niskim cieple hydratacji siarczanoodporny niskoalkaliczny CEM III/A 42,5 N LH/HSR/NA wyprodukowany na potrzeby projektu w Oddziale Szkła i Materiałów Budowlanych w Krakowie, a którego właściwości przedstawiono w [5]. Zmienną materiałową w mieszankach betonowych stanowił rodzaj użytego kruszywa grubego. Mieszanka odniesienia została wykonana z grysem amfibolitowym z kopalni Ogorzelec. Kruszywa specjalne stanowiły: baryt $\mathrm{z}$ niemieckiej kopalni w Wolfach, magnetyt z Kiruny w Szwecji oraz serpentynit z Nasławic. Oznaczenie mieszanek stanowiła pierwsza litera rodzaju użytego kruszywa grubego (Tabela 1). Zastosowano także superplastyfikator na bazie zmodyfikowanych fosfonianów. Stwierdzono trudności w uzyskaniu wymaganej konsystencji w betonie z kruszywem serpentynitowym. Stąd ilość użytej dozowanej domieszki była kilkukrotnie większa niż w pozostałych mieszankach i wynosiła $4,8 \%$ masy cementu.

Tabela 1. Skład i właściwości mieszanek betonowych, wytrzymałość betonu na ściskanie

Table 1. Mix design, fresh mix properties and compressive strength of concrete

\begin{tabular}{|c|c|c|c|c|}
\hline Skład $\left[\mathrm{kg} / \mathrm{m}^{3}\right]$ & $\mathbf{A}$ & $\mathbf{S}$ & $\mathbf{M}$ & B \\
\hline Cement & 350 & 350 & 350 & 350 \\
\hline Woda & 168 & 168 & 168 & 168 \\
\hline Piasek kwarcowy 0-2 mm & 371 & 371 & 371 & 371 \\
\hline Amfibolit 2-8 mm & 1115 & - & - & - \\
\hline Amfibolit 8-16 mm & 507 & - & - & - \\
\hline Magnetyt $0,5-5 \mathrm{~mm}$ & - & - & 839 & - \\
\hline Magnetyt 0-16 mm & - & - & 1846 & - \\
\hline Serpentynit 2-6 mm & - & 909 & - & - \\
\hline Serpentynit 8-16 mm & - & 545 & - & - \\
\hline Baryt 0-16 mm & - & - & - & 2349 \\
\hline Superplastyfikator [\% m.c.] & 0,70 & 4,80 & 0,60 & 0,48 \\
\hline Opad stożka [mm] & 80 & 60 & 100 & 100 \\
\hline Gęstość mieszanki $\left[\mathrm{kg} / \mathrm{m}^{3}\right]$ & 2500 & 2340 & 3570 & 3240 \\
\hline $\left.\mathrm{f}_{\mathrm{c}} 7[\mathrm{MPa}]^{*}\right)$ & $\begin{array}{l}45,2 \\
\end{array}$ & 33,4 & 38,1 & 37,0 \\
\hline $\left.\mathrm{f}_{\mathrm{c}} 28[\mathrm{MPa}]^{*}\right)$ & 68,2 & 59,7 & 64,2 & 54,3 \\
\hline $\left.\mathrm{f}_{\mathrm{c}} 90[\mathrm{MPa}]^{*}\right)$ & 86,3 & 78,6 & 82,6 & 59,6 \\
\hline
\end{tabular}

'średnia wytrzymałość na ściskanie wykonana na 3 próbkach 100x100x100 mm

Szczególną uwagę poświęcono dobraniu właściwego uziarnienia stosu okruchowego, tak aby uzyskać zbliżony rozkład ziarnowy między projektowanymi betonami (Rys. 1). W celu spełnienia założeń zastosowano technikę kruszenia kruszarką szczękową oraz selektywnej separacji ziarnowej za pomocą przesiewania sitowego na sucho. Ustalanie stosu okruchowego uwzględniało różnicę gęstości pomiędzy piaskiem kwarcowym, a zastosowanym kruszywem ciężkim. 


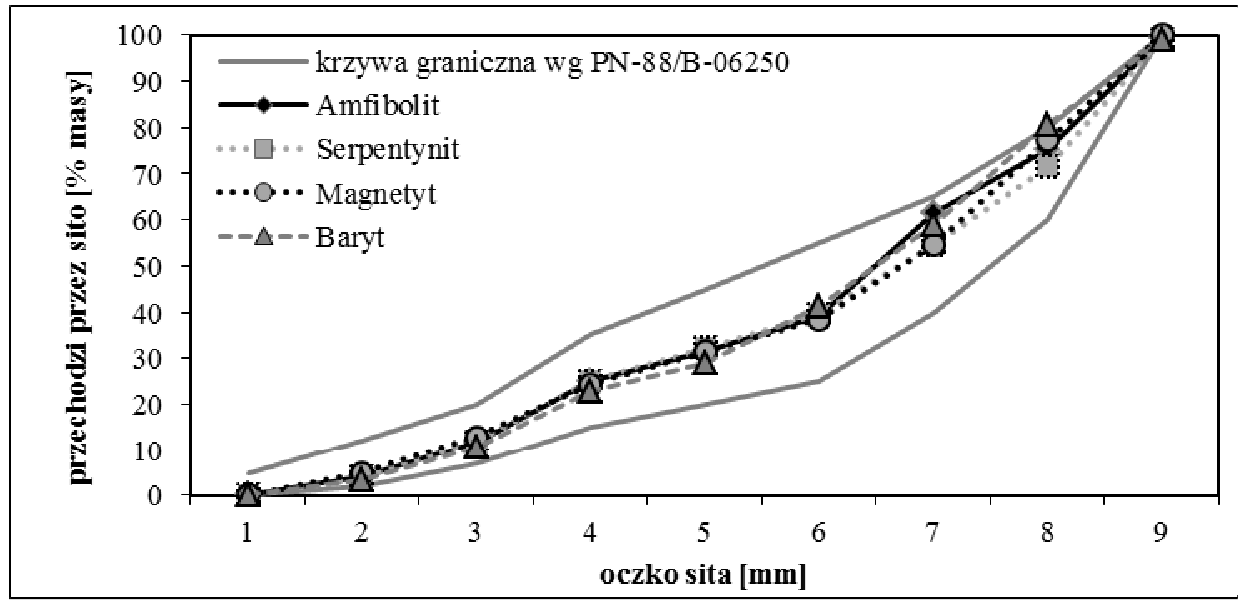

Rys. 1. Krzywe uziarnienia kruszyw

Fig. 1. Aggregate gradation curves

$\mathrm{Z}$ mieszanek wykonanych w mieszarce o pojemności 60 litrów wykonano próbki sześcienne o boku $100 \mathrm{~mm}$ do badania wytrzymałości na ściskanie. Wykonane próbki $\varnothing 100 \times 200 \mathrm{~mm}$ wykorzystano w oznaczaniu współczynników absorpcji wody, porowatości dostępnej dla wody oraz współczynnika migracji jonów chlorkowych. Z próbek sześciennych o boku $100 \mathrm{~mm}$ wykonano odwierty $\varnothing 9 \times 20 \mathrm{~mm}$ do badań w porozymetrze rtęciowym. Próbki były przechowywane w normowych warunkach wysokiej wilgotności i stałej temperatury przez 56 dni $\left(\mathrm{RH}>95 \%, 20 \pm 2^{\circ} \mathrm{C}\right)$.

\subsection{Metody badań}

Badanie wytrzymałości na ściskanie przeprowadzono zgodnie z normą PNEN 12390-3.

Określenie współczynnika absorpcji wody $I \mathrm{w}$ stwardniałym betonie przeprowadzono zgodnie z normą ASTM C1585-13. Na podstawie zmiany masy próbek w funkcji czasu wywołanej zanurzeniem badanej powierzchni próbki w wodzie wyznaczono współczynnik początkowej szybkości absorpcji $S_{i}$ oraz wtórnej szybkości absorpcji wody $S_{s}$. Badania przeprowadzono na 2 próbkach o średnicy $100 \mathrm{~mm}$ i wysokości $50 \pm 3 \mathrm{~mm}$.

Oznaczenie porowatości dostępnej dla wody $E$ wykonano zgodnie z normą francuską NF P18-459:2010. Próbki zostały nasycone próżniowo wodą, a następnie ważone w trzech stanach nasycenia wodą: całkowicie nasycone ważone wagą hydrostatyczną, całkowicie nasycone ważone wagą analityczną, oraz wysuszone do stałej masy $\mathrm{w} 105^{\circ} \mathrm{C}$. Na podstawie różnic między pomiarami wy- 
znaczono wartość porowatości dostępnej dla wody. Badanie przeprowadzono na 3 próbkach o średnicy $100 \mathrm{~mm}$ i wysokości $50 \pm 3 \mathrm{~mm}$.

Do określenia odporności betonu na wnikanie jonów chlorkowych zastosowano przyspieszoną metodę oznaczania migracji jonów, opisaną w normie NT Build 492. Współczynnik migracji jonów chlorkowych $D_{n s s m}$ wyznaczony został przy nieustalonym przepływie strumienia jonów, wywołanym zewnętrznym polem elektrycznym. Każdorazowo badaniu poddano trzy próbki betonu o średnicy $100 \mathrm{~mm}$ i wysokości $50 \pm 3 \mathrm{~mm}$. Pełen opis metody podano w [6]. Przyjęto kryteria oceny odporności na wnikanie jonów chlorkowych zaproponowane przez L. Tanga w [7]: kategoria ,,bardzo dobra”, gdy $\mathrm{D}_{n s s m}<2 \times 10^{-12} \mathrm{~m}^{2} / \mathrm{s}$, ,dobra”, gdy $D_{n s s m}=2-8 \times 10^{-12} \mathrm{~m}^{2} / \mathrm{s}$, ,dopuszczalna”, gdy $D_{n s s m}=8-16 \times 10^{-12} \mathrm{~m}^{2} / \mathrm{s}$ $\mathrm{i}$,niedopuszczalna”, gdy $\mathrm{D}_{n s s m}>16 \times 10^{-12} \mathrm{~m}^{2} / \mathrm{s}$.

Rozkład wielkości porowatości kapilarnej w betonach oznaczono za pomocą metody porozymetrii rtęciowej (MIP). Badanie wykonano w AGH w Krakowie na porozymetrze rtęciowym PoreMaster 60 firmy Quantachrome Instruments. Badanie przeprowadzono na fragmentach matryc cementowych wyselekcjonowanych $\mathrm{z}$ trzech odwiertów rdzeniowych, tak aby nie zawierały ziaren kruszywa grubego. Kryterium wielkości próbki stanowiła objętość komory urządzenia pomiarowego, o wymiarach $\emptyset 10 \times 25 \mathrm{~mm}$.

\section{Wyniki badań}

Niekorzystny wpływ zastosowania kruszyw specjalnych jest widoczny na podstawie rezultatów badania wytrzymałości na ściskanie (Tabela 1). Największe różnice występują po 7 dniach dojrzewania i wynoszą od $15 \%$ do $27 \%$ w porównaniu $\mathrm{z}$ betonem referencyjnym. Jednakże wytrzymałość po 90 dniach dojrzewania znacząco różni się jedynie w przypadku zastosowania kruszywa barytowego (mieszanka B) i jest mniejsza od betonu referencyjnego o $30 \%$.

Na podstawie rezultatów badania absorpcji wody stwierdzono, że kruszywo magnetytowe (mieszanka $\mathrm{M}$ ) nie powoduje pogorszenia szczelności betonu $\mathrm{w}$ porównaniu $\mathrm{z}$ betonem referencyjnym $\mathrm{z}$ kruszywem amfibolitowym (mieszanka A). Natomiast zastosowanie kruszyw serpentynitowego i barytowego pogarsza trzykrotnie współczynniki $S_{i}$ i $S_{s}$ (Rys. 2).

W badanych próbkach betonu stwierdzono nieznaczne różnice objętości porów dostępnych dla wody $(E)$ między seriami, których różnica nie przekraczała $1,5 \%$ (Rys. 3). Najniższą wartość współczynnika $E$, wynoszącą $12,8 \%$, wykazał beton referencyjny (mieszanka A). Nieznacznie większą wartość uzyskał beton z kruszywem magnetytowym - wynosiła ona $13,2 \%$. Następnie betony oznaczone S i B, których współczynnik $E$ wynosił odpowiednio $13,7 \%$ i $14,2 \%$. Na podstawie kryteriów oceny wyników współczynnika $E$ [8],[9], powyższe wyniki można zaklasyfikować jako ,dobre”. 


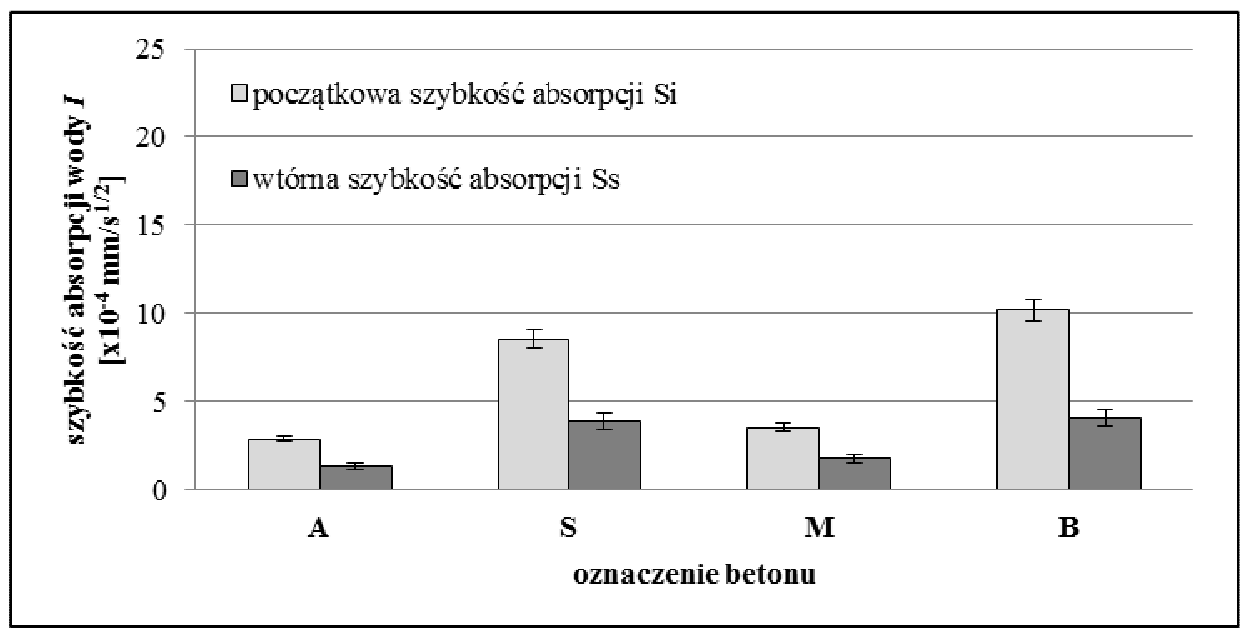

Rys. 2. Początkowa i wtórna szybkość absorpcji wody

Fig. 2. Initially and secondary rate of water absorption

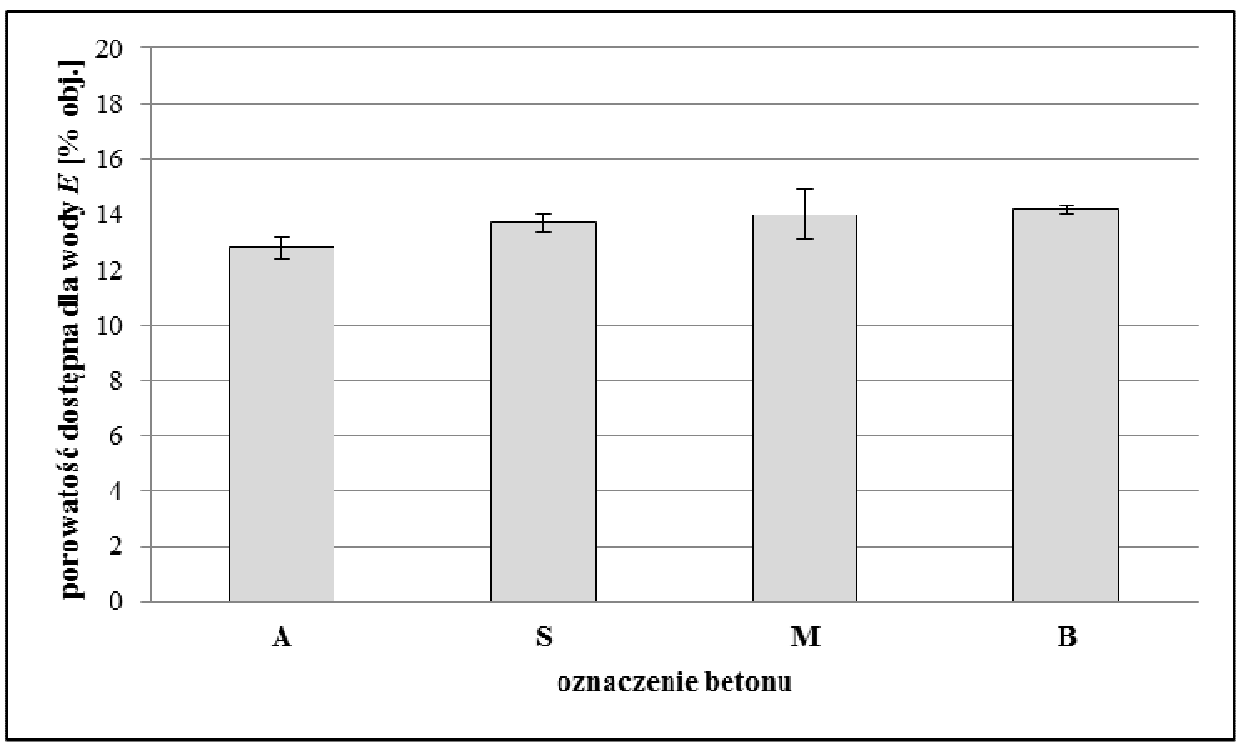

Rys. 3. Porowatość dostępna dla wody

Fig. 3. Porosity available for water

Analizując wyniki badań współczynnika migracji jonów chlorkowych $D_{n s s m}$ (Rys. 4) stwierdzić można, że beton oznaczony A, będący betonem odniesienia oraz beton wykonany z kruszywem barytowym (mieszanka B), wykazały najniższą przepuszczalność jonów chlorkowych, odpowiednio $D_{n s s m}=3,7 \times 10^{-12} \mathrm{~m}^{2} / \mathrm{s}$ oraz $D_{n s s m}=3,8 \times 10^{-12} \mathrm{~m}^{2} / \mathrm{s}$, zaklasyfikowaną do ,dobrej” kategorii odporności 


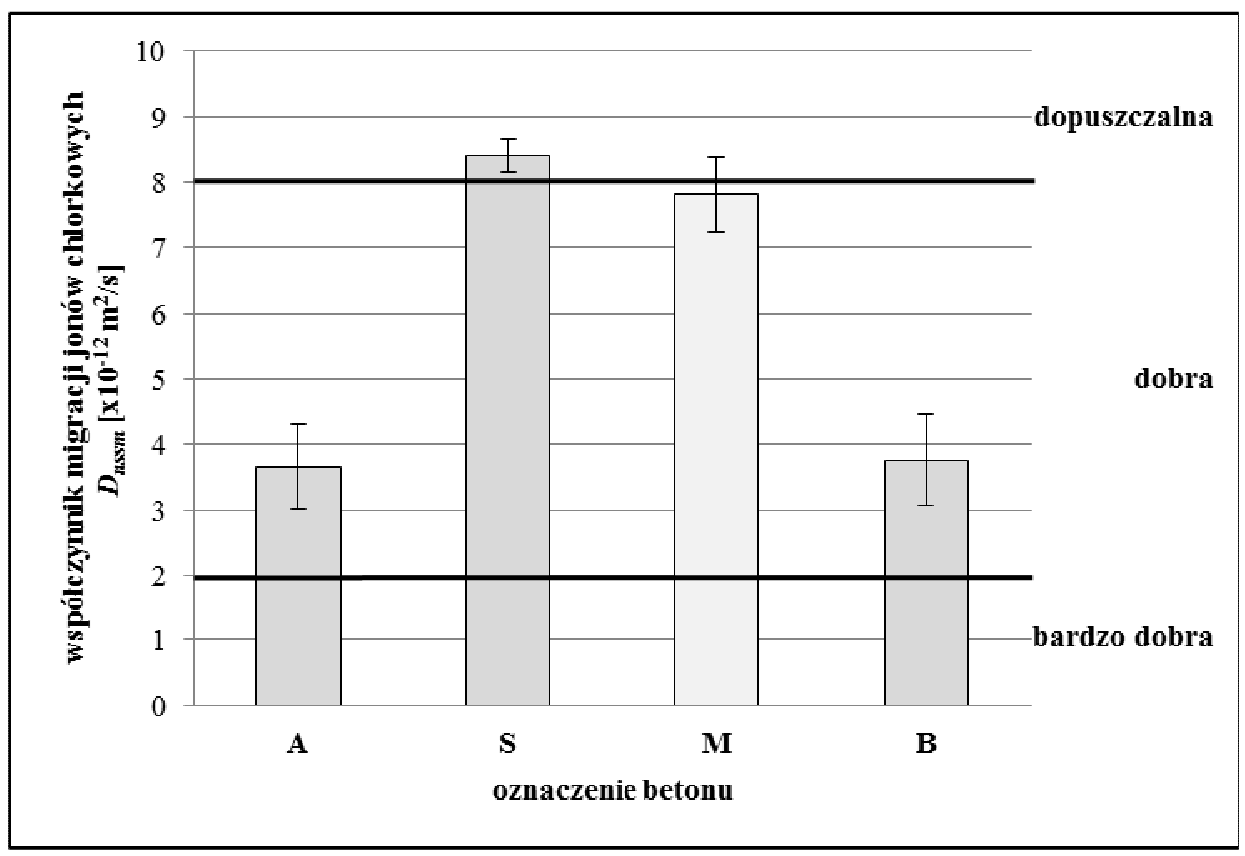

Rys. 4. Wyniki badań współczynnika migracji jonów chlorkowych. Liniami poziomymi zaznaczono umowne granice pomiędzy kategoriami odporności na wnikanie jonów chlorkowych

Fig. 4. Chloride ions migration coefficient. The horizontal lines are the limits for classification of resistance to chloride migration

na wnikanie jonów chlorkowych. Beton wykonany z kruszywem serpentynitowym (mieszanka S) wykazał odporność na granicy „dobrej” i „dopuszczalnej”, współczynnik $D_{n s s m}$ osiągnął dwukrotnie wyższą wartość od betonu odniesienia $\left(D_{n s s m}=8,4 \times 10^{-12} \mathrm{~m}^{2} / \mathrm{s}\right)$. Natomiast beton zawierający kruszywo magnetytowe (mieszanka M) nie spełnił wymagań normowych dotyczących wymaganego poziomu początkowego natężenia prądu, dlatego otrzymany wynik uznano za niewiarygodny i nie został on poddany analizie.

Wykorzystanie techniki porozymetrii rtęciowej pozwoliło na ocenę rozkładu wielkości porów kapilarnych w stwardniałym betonie. Zaproponowany sposób pobierania i przygotowywania próbek do badań pozwala przypuszczać, że w pomiarach porozymetrii rtęciowej mierzony był jedynie wpływ najdrobniejszych frakcji kruszyw specjalnych na porowatość matrycy cementowej. W badanych betonach stwierdzono znaczące różnice w dystrybucji oraz całkowitej objętości porów kapilarnych (Rys. 5). Beton z serpentynitem (mieszanka S) uzyskał największą objętość porów kapilarnych wynoszącą $0,054 \mathrm{~cm}^{3} / \mathrm{g}$ oraz miał inny rozkład zawartości porów w odniesieniu do pozostałych betonów. Beton referencyjny uzyskał całkowitą objętość porów kapilarnych wynoszącą $0,046 \mathrm{~cm}^{3} / \mathrm{g}$. Natomiast betony z kruszywami ciężkimi magnetytowym i baryto- 
wym uzyskały odpowiednio wartości o $30 \%$ i $53 \%$ mniejsze. Powyższe różnice wynikają ze zmian w zawartości najliczniejszych porów kapilarnych, których średnica zawiera się w przedziale od $40 \mathrm{~nm}$ do $1000 \mathrm{~nm}$. Głównie ich zawartość wpłynęła na zmianę całkowitej objętości porów między betonami. Jedynie w betonie z serpentynitem (mieszanka $S$ ) przedział średnic najliczniejszych porów wynosił od $20 \mathrm{~nm}$ do $100 \mathrm{~nm}$ i stanowił 70\% całkowitej porowatości.

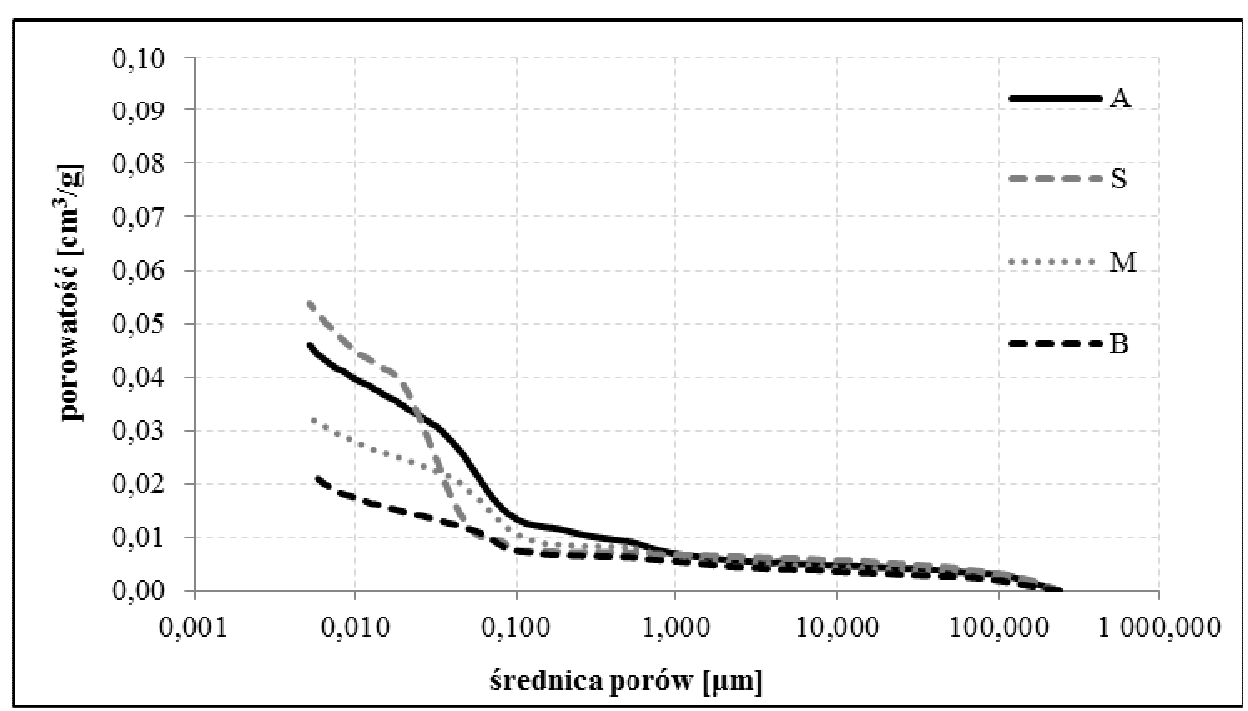

Rys. 5. Wzrost udziału porowatości kapilarnej wraz ze zmniejszającą się średnicą porów

Fig. 5. Volume of porosity with increase of pore diameter

Zdecydowanie odmienna mikrostruktura betonu oznaczonego S od pozostałych betonów pozwala w sposób pośredni skomentować niekorzystny wpływ kruszywa serpentynitowego na uzyskane wyniki $D_{n s s m}, E, S_{i}, S_{s}$. Z rozkładu porowatości kapilarnej wynika, że betony z kruszywami magnetytowym i barytowym o niewielkiej całkowitej objętości porów powinny stanowić materiał o lepszej szczelności w porównaniu z betonem referencyjnym. Jednakże w przypadku betonu z barytem wyniki podciągania kapilarnego i porowatości dostępnej dla wody przedstawiają dokładnie odwrotne spostrzeżenia.

\section{Wnioski}

Przeprowadzone badania pozwalają na sformułowanie następujących wniosków:

- Wytrzymałość na ściskanie betonów z kruszywami specjalnymi osiąga wartości niższe niż betonu referencyjnego z kruszywem amfibolitowym; w przypadku betonu z kruszywem barytowym wytrzymałość na ściskanie jest o 30\% 
niższa po 90 dniach dojrzewania.

- Zastosowanie kruszywa serpentynitowego zwiększa współczynnik $D_{n s s m}$, objętość porów dostępną dla wody oraz początkową i wtórną szybkość absorpcji wody względem betonu referencyjnego.

- Zastosowanie w betonie kruszywa serpentynitowego zwiększyło o 16\% całkowitą objętość porów kapilarnych względem kompozytu referencyjnego. W przypadku pozostałych kruszyw, magnetytowego i barytowego, wpływ był przeciwny, a całkowita objętość porów kapilarnych była mniejsza o odpowiednio $30 \%$ i $53 \%$.

Referat zostat przygotowany w ramach Projektu „Trwatość i skuteczność betonowych oston przed promieniowaniem jonizujacym $w$ obiektach energetyki jadrowej”, PBSII/A2/15/2014.

\section{Literatura}

[1] Kaplan M.F.: Concrete radiation shielding: nuclear physics, concrete properties, design and construction, Longman Scientific\&Technical, Harlow, England.

[2] Bangash M.Y.H.: Structures for Nuclear Facilities: Analysis, Design, and Construction, Springer-Verlag, Berlin Heidelberg.

[3] Bazant Z.P., Kaplan M.D.: Concrete at High temperatures; Material properties and mathematical Models, Longman, London 1996.

[4] Dąbrowski M., Glinicki M.A., Nowowiejski G.: Zastosowanie kruszyw specjalnych w projektowaniu betonów osłonowych o podwyższonej trwałości, Cement Wapno Beton 2016 (w przygotowaniu).

[5] Baran T., Glinicki M.A., Jóźwiak-Niedźwiedzka D.: Właściwości cementów specjalnych przeznaczonych do betonu w konstrukcjach osłonowych elektrowni jądrowych, Cement Wapno Beton, vol 21/83, no 3, 2016.

[6] Glinicki M.A., Jóźwiak-Niedźwiedzka D., Gibas K., Dąbrowski M.: Influence of blended cements with calcareous fly ash on chloride ion migration and carbonation resistance of concrete for durable structures, MATERIALS, DOI: 10.3390/ma9010018, vol.9, no.1, 2016, pp. 18-1-15.

[7] Tang L.: Chloride transport in concrete - Measurement and prediction, Publication P96:6, Chalmers University of Technology, Department of Building Materials, Göteborg 1996.

[8] Baroghel-Bouny V.: Durability indicators: relevant tools for performance-based evaluation and multi-level prediction of RC Durability, RILEM Workshop on Performance Based Evaluation and Indicators for concrete Durability, Madryt 2006, pp. 3-30.

[9] Glinicki M.A.: Długotrwała funkcjonalność betonu w konstrukcjach osłonowych elektrowni jądrowych, IPPT PAN, Warszawa 2015. 


\section{INFLUENCE OF SPECIAL AGGREGATES ON POROSITY AND PERMEABILITY OF RADIATION-SHIELDING CONCRETES}

\section{S u m m a r y}

In the paper test results are presented of capilarity $(P K)$, porosity accessible for water $(E)$ and of the chloride ions migration coefficient in the non-steady state $\left(D_{n s s m}\right)$. The scope of investigations covered concretes with magnetite, barite, serpentinite aggregates as well as with reference amfibolite aggregate, which was crushed and selected in order to ensure the same granularity. The influence of microporosity was determined by mercury porosimetry together with ion and moisture tightness of cement matrix.

It was concluded after the tests that concretes with special aggregates are characterized by the permeability comparable or worse than reference specimens. The most unfavourable results were obtained in the specimens with serpentinite aggregate. The regular influence of capillary porosity on the permeability was not observed.

Keywords: Sorptivity, chloride ions migration, porosity accessible for water, magnetite aggregate, barite aggregate, serpentinite aggregate

Przestano do redakcji: 07.06.2016 $r$.

Przyjęto do druku: 30.06.2016r.

DOI: $10.7862 / r b .2016 .11$ 